Int. J. Dev. Biol. 66: 97-102 (2022)

https://doi.org/10.1387/ijdb.210120nk

\title{
Exosomes and the extracellular matrix: a dynamic interplay in cancer progression
}

\author{
ASIMINA KARAMPOGA\#, KYRIAKI TZAFERI\#, CHRISTOS KOUTSAKIS, \\ KONSTANTINA KYRIAKOPOULOU, NIKOS K. KARAMANOS* \\ Biochemistry, Biochemical Analysis and Matrix Pathobiology Research Group, Laboratory of Biochemistry, \\ Department of Chemistry, University of Patras, Greece
}

\begin{abstract}
Exosomes are a subtype of extracellular vesicles (EVs) composed of a lipid bilayer, which carry various cargoes such as nucleic acids, proteins, and bioactive lipids. Cancer cells release exosomes to promote cell communication and interaction with the extracellular matrix (ECM). ECM regulates the secretion and uptake of exosomes. Moreover, the cargo of exosomes can control ECM remodeling, thus affecting cancer progression. Aside from the rearrangement of ECM, exosomal cargo also modulates different signaling pathways that maintain homeostasis and play a major role in tumor growth and immune evasion in the tumor microenvironment (TME). Exosomes are now widely recognized as circulating biomarkers for diagnosis and prognosis. Their role in cancer initiation, progression, and chemoresistance is becoming increasingly clear from preclinical and clinical investigations, thereby gaining interest for their potential use as cancer diagnostics tools, but also for the development of future innovative cancer therapeutics. In this mini review we outline and discuss the correlation between exosomes, TME and cancer progression, while focusing on the potential role of exosomes as diagnostic and prognostic biomarkers, as well as therapeutic vehicles for drug delivery.
\end{abstract}

KEYWORDS: exosomes, extracellular matrix, tumor microenvironment, cell communication, cancer

\section{Introduction}

Cell-cell communication drives cellular activities and tissue homeostasis in both physiological and pathological conditions. A part of this communication is carried out via the release of nanosized, membrane-bound vesicles, which can transfer different kinds of cargo such as DNA, RNA, and proteins. These extracellular vesicles (EVs) are released by virtually all cells, as part of their normal function as well as after acquired disorders. A major category of EVs that assist in intercellular communication are exosomes, with a variety of sizes ranging from 40 to 120 nanometers. Due to their size, they constitute an accessible and efficient source of cell information, compared to traditional biomarkers. Exosomes were first identified in the early ' 80 s, when scientists observed that transferrin receptors related with microscopic vesicles are actually discarded into the extracellular environment by blood reticulocytes (Harding, C., Stahl, 1983). In the human body, these vesicles can be found in a variety of bodily fluids including plasma, saliva and breast milk (Chernyshev et al., 2015).
Despite once being treated as cellular waste and therefore underappreciated, exosomes are now considered key vehicles of intercellular communication and it is well established that tumor microenvironment (TME) correlates to their formation and secretion (Karamanos et al., 2021). In addition, exosomes can affect tumor growth and metastasis directly through the exosome-mediated signaling, but they can also have a significant impact on several critical events of the metastatic cascade and the induction of epithelial-to-mesenchymal transition (EMT), mainly due to the fact that their cargo contains extracellular matrix (ECM) degradation

\begin{abstract}
Abbreviations used in this paper: CAFs, cancer-associated fibroblasts; CAMs, cell adhesion molecules; circRNA, circular RNA; ECM, extracellular matrix; EMT, epithelial-to-mesenchymal transition; ESCRT, the endosomal sorting complex necessary for transport; ESE, early-sorting endosome; EVs, extracellularvesicles; HIF-1a, hypoxia inducible factor-1 alpha; ILVs, intraluminal vesicles; IncRNA, long noncoding RNA; MMPs, metalloproteinases; MVBs, multivesicularbodies; ncRNA, non-coding RNA; PGs, proteoglycans; shRNA, short hairpin RNA; siRNA, small interfering RNA; SNARE, soluble N-ethylmaleimide-sensitive factor attachment protein receptor; TME, tumor microenvironment; TfR, transferrin receptors.
\end{abstract}

*Address correspondence to: Nikos K. Karamanos. Department of Chemistry, University of Patras, University Campus Rio, GR26504, Patras, Greece. Tel: +30 2610997915.
E-mail: n.k.karamanos@upatras.gr | web: http://www.chem.upatras.gr/faculty/karamanos | https://orcid.org/0000-0003-3618-0288

"Equal contribution

Submitted: 22 July, 2021; Accepted: 17 August, 2021; Published online: 20 September, 2021.

ISSN: Online 1696-3547, Print 0214-6282

(C) 2021 UPV/EHU Press

Printed in Spain 

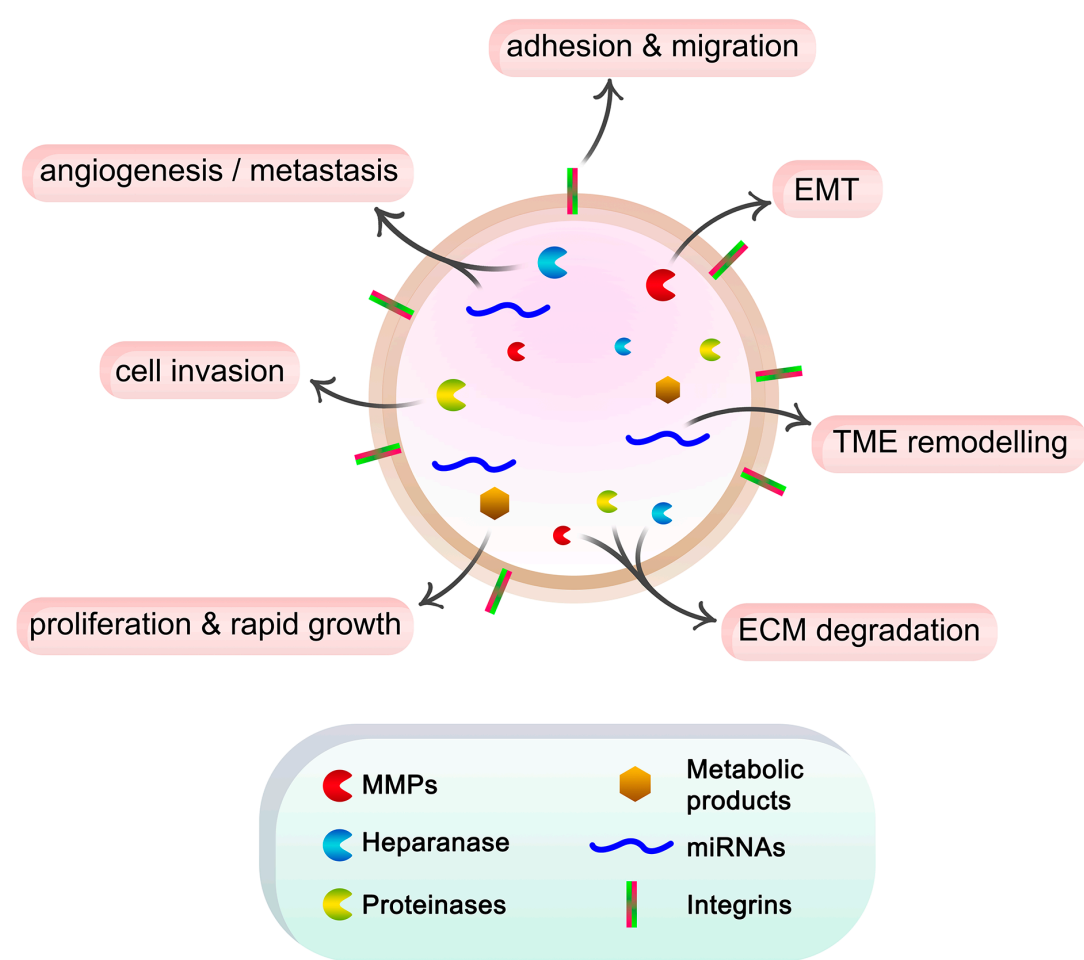

Fig. 1. Schematic representation of the roles of exosome cargo in cancer progression. Cancer cells secrete exosomes containing ECM degradation enzymes such as MMPs, heparanase and other proteinases, miRNAs, and metabolic products. These components in turn affect cell function, promote EMT, form pre-metastatic niches, and induce angiogenesis and metastasis. Additionally, the integrins on the exosome surface can interact with ECM components, stimulating cell adhesion and migration.

enzymes (Giordano et al., 2020). In this article, we present insights in respect to the formation of exosomes, their role in TME, and the current outlook on exosome targeting strategies and clinical approaches.

\section{Exosome biogenesis and composition}

Exosome biogenesis is a unique protein quality control procedure that enables cells to remove proteins from the plasma membrane promptly and selectively. Once secreted from the cell, exosomes can become important components of the ECM and as a result, provide a way for cells to modify their composition and function. This way, they are able to both transmit signals and transfer chemicals via an intercellular vesicle trafficking pathway (Pegtel and Gould, 2019).

Exosomes are formed by the double invagination of the cell membrane and the synthesis of intracellular multivesicular bodies (MVBs) that include intraluminal vesicles (ILVs). After the MVB fusion to the plasma membrane and exocytosis, ILVs are eventually released as exosomes. The earliest step of the biogenesis procedure is the cup-shaped structure which is formed from the first invagination of the plasma membrane and includes cell-surface proteins as well as soluble proteins from the extracellular environment. This contributes to the de novo development of an earlysorting endosome (ESE), which can combine with a pre-existing
ESE under specific conditions. The ESE's development and composition can be further modified by the trans-Golgi network and endoplasmic reticulum.

Different processes are thought to be involved in the formation itself. To generate an inward-budding vesicle within the endocytic system, namely exosomes, or in case of microvesicles, an outward-budding vesicle at the plasma membrane, lipid curvature must be induced. The best-known mechanism is the recruitment of the endosomal sorting complex necessary for transport (ESCRT) machinery, which consists of four protein complexes (ESCRT-0, -I, -II, and -III) and accessory proteins (Alix, VPS4, and VTA-1), to ubiquitinated proteins in the early endosome (Maas et al., 2017). Notably, some exosomes released from cells into the extracellular space by a process that is not dependent on ESCRT (Trajkovic, 2008). For example, exosome release is considered dependent on the sphingomyelinase enzyme rather than ESCRT. CD63, CD9 and CD81, as well as other plasma membrane proteins, are frequently detected in exosomes and are often concentrated in vesicles rather than cell lysate (van Niel et al., 2011).

A number of proteins and complexes are involved in the biogenesis of exosomes, such as the Rasrelated protein GTPase Rab, Sytenin-1, phospholipids, tetraspanins, ceramides, sphingomyelinases, and soluble $\mathrm{N}$-ethylmaleimide-sensitive factor attachment protein receptor (SNARE), although their functions and roles in exosome formation require additional investigation, particularly in vivo (Mathieu et al., 2019).Upon biogenesis, exosomes are picked up by recipient cells via endocytosis, receptor-ligand binding, or cell membrane fusion. Exosome uptake is controlled by interactions between exosome surface proteins and recipient cells. Exosome adhesion-associated molecules on the surface, such as tetraspanins and integrins, have been hypothesized to determine which cells receive exosomes (Zhang and Yu, 2019).

A variety of molecules, such as receptors, transcription factors, enzymes, ECM components, lipids, and nucleic acids can be found within exosomes, as well as on their surface (Fig. 1). Exosome protein composition analysis indicates that some proteins are unique to the tissue or cell of origin, while others are found in almost all exosomes. They include adhesion molecules such as cell adhesion molecules (CAMs), integrins, tetraspanins, MHC class I/II, and transferrin receptors (TfRs) on the surface of $B$ lymphocytes, dendritic cells and reticulocytes. Non-specific exosome protein types include fusion and transferring proteins like Rab2, Rab7, flotillin, and annexin, heat shock proteins like Hsc70 and Hsc90, cytoskeleton proteins like actin, myosin, and tubulin, and proteins like Alix that mediate MVB formation (Van Niel et al., 2006). Besides that, exosome lipid content is either cell-specific or conserved. Lipids are involved in exosome production and also control homeostasis in recipient cells, and maintain the exosome shape. (Mashouri et al., 2019). According to the most recent lists in the exosome online database ExoCarta (www.exocarta. org), exosomes contain a range of components, including 9,769 proteins, 3,408 mRNAs, 2,838 miRNAs, and 1,116 lipids. 


\section{ECM as mediator of exosome secretion and uptake}

As already stated, exosomes facilitate cell-cell communication and cell-matrix interactions. In particular, cancer cells use this mode of communication for reprograming, located in often remote locations, such as bone marrow progenitor cells, cancer-associated fibroblasts (CAFs), tumor-related macrophages and neutrophils to form appropriate pre-metastatic niches (Qadir et al., 2018).

The TME appears to modulate the formation and secretion of exosomes, thereby participating in tumor progression. Notably, ECM hardening observed during tumor growth is associated with the risk of metastasis, due to the high deposition of ECM components, including collagen. Increased type I collagen accumulation and Apc mutation in colon adenocarcinoma (CRC) stimulate exosome release. This mutation also induces the Wnt signaling pathway, a critical pathway for the intestinal epithelium and enteric adenomas, further enhancing exosome release (Szvicsek et al., 2019). Moreover, the mechanical properties and the organization of collagen fibers affect the behavior of cancer cells (Jung et al., 2020). For instance, at early stages of breast cancer growth, collagen fibers are arranged in a parallel pattern, preventing cell invasion. As the tumor expands, the pressure exerted on the collagen fibers results in radially aligned fibrils, where exosomes are more easily diffused (Franchi et al., 2020).

The observed synergy between exosomes and ECM can also directly affect cancer progression and growth. For instance, exosome-mediated signaling induces hypoxia, which in turn advances tumor progression, angiogenesis and metastasis. On the other hand, hypoxia can cause the production of exosomes by cancer cells through hypoxia inducible factor- 1 alpha (HIF-1a). In addition, exosomes secreted by hypoxic cancer cells provoke focal adhesion and invasion, while also promoting cancer cell survival and metastasis, due to the modified secretion of epidermal growth factor that binds heparin via exosomes. This modification is induced by the activation of BHLHE40, indicating that this axis is an important mechanism, leading to breast cancer metastasis (Tan et al., 2021). Additionally, exosome levels in serum of breast cancer patients are higher in comparison to healthy individuals, while exosomes produced by fibroblasts determine breast cancer cells migration (Melo et al., 2014).

The binding and uptake of exosomes by receptor cells is carried out through ECM proteins and their receptors. This is confirmed by the fact that enrichment of pancreatic adenocarcinoma-derived exosomes with VCAM-1 and integrin a 4 increase their binding and uptake by endothelial cells. In addition, various studies have shown that receptor cells not expressing cell surface proteoglycans (PGs) cannot internalize exosomes as effectively as those that do express them. These PGs bind to lectins on the surface of exosomes, whereas the absence of heparan sulfate proteoglycan receptors reduces the uptake of exosomes (French et al., 2017). Nevertheless, among PGs, cell-membrane syndecans can also affect the formation of exosomes via ESCRT III, as it binds to the protein ALIX by the small cytosolic adapter protein syntenin. Moreover, the cleavage of heparan sulfate chains by heparanase leads to the accumulation of syndecans that activate exosome production by the syndecanALIX-ESCRT axis (Bebelman et al., 2018). Therefore, heparanase is an important regulator of the secretion, composition and function of exosomes. The presence of heparanase has also been shown to increase exosome production and affect the synthesis of exo- some proteins. In addition, exosomes derived from cancer cells, with high levels of heparanase expression, modify cancer cells behavior (Piperigkou et al., 2021). Finally, exosome delivery can be regulated by the ASPH (asparaginyl $\beta$-hydroxylase)-Notch axis. This axis causes ECM remodeling through the action of MMPs and ADAMs, promoting cell invasiveness and directing the delivery of exosomes (Tan et al., 2021). In particular, it appears that ASPH leads malignant breast cancer cells to synthesize and produce exosomes with a specific cargo, which will bring about changes in key processes of the less malignant cells (Lin et al., 2019).

\section{Exosomal cargo affects ECM remodeling promoting cancer}

The exosomal cargo can contain proteins, signaling molecules and microRNAs. These components are involved in cytoskeletal remodeling, invasiveness and cell motility, while also controlling signaling pathways that regulate migration and angiogenesis and direct primary cancer cells to specific metastatic sites.

Cancer cell-derived exosomes can contain metabolic products, which directly induce rapid growth and proliferation of cancer cells in a paracrine manner. (Tan et al., 2021). In addition, exosomes are rich in ECM degradation enzymes like metalloproteinases (MMPs). Notably, it has been shown that the transfer of exosomes from high metastatic MDA-MB-231 breast cancer cells to non-tumorigenic MCF-10A epithelial breast cancer cells leads to increased expression of MMP-2 and MMP-9 and induction of EMT (Galindo-Hernandez et al., 2014; Yang et al., 2020). Similarly, ovarian cancer exosomes contain MMP-2, MMP-9 and UPA, leading to ECM degradation (Rilla et al., 2019). In cancer cells and CAFs, the major MMP regulating collagen degradation is MT1-MMP, mainly found in actin-rich invasive cell structures, termed invadopodia. The release of proteinases from exosomes induces the maturation and stability of invadopodia, ECM degradation and favors cell invasion (Hoshino et al., 2013). Thus, it seems that there is a direct correlation between invadopodia formation and exosome release (Winkler et al., 2020).

Besides MMPs, another enzyme found in exosomal cargo is heparanase, allowing its release in distant areas. Since this enzyme induces angiogenesis and metastasis, its transport via exosomes is crucial for the formation of pre-metastatic niches, where cancer cells will settle and grow (Piperigkou et al., 2021). miRNAs transferred by exosomes are important factors for cell communication as well as the regulation of metastasis, angiogenesis, TME formation and remodeling (Tan et al., 2021). What is more, exosomes derived from metastatic cancer cells can penetrate the blood-brain barrier and disrupt its function. For example, vascular endothelial cell-derived exosomes contain miR-105 and miR-181c and are able to destroy vascular endothelial barriers, causing tumor metastasis to the brain (Tai et al., 2018).

Furthermore, exosomes contain adhesion receptors on their surface, such as integrins. Through integrins, exosomes bind to fibronectin and thus local secretion of exosomes promotes adhesion and contributes to increased cell migration. It is important to note that integrins expressed by breast cancer cell exosomes target specific organs to which they attach themselves, defining the location of future metastasis (Winkler et al., 2020). Likewise, exosomal fibronectin has been shown to facilitate breast cancer metastasis in vivo. This is achieved by increasing the production of proinflammatory cytokines and MMP-9 (Tan et al., 2021). Apart 
from fibronectin, exosomal integrins can interact with other ECM components, such as laminins. The deposition of laminins increases cell adhesion, facilitating the colonization of cancer cells (Guo et al., 2019). Similarly, exosomes derived from pancreatic and colon cancer cells have been found to carry an adhesion protein, CD44v6, which interacts with integrins a 6 and $\beta 4$ to enhance cell migration and invasion (Paolillo and Schinelli, 2017).

\section{Exosomes in disease diagnosis and therapy}

The heterogeneity of exosome cargo could be used as disease diagnosis and prognosis tools. Therefore, exosomes make suitable candidates as cancer biomarkers. For instance, exosomal miRNAs can be a useful tool for prognosis and/or grading during cancer progression. Several miRNAs could serve as biomarkers, including miR-451a, miR-21, miR-499, miR-133, miR-208, miRNA-34a, and miR-638 (Zhang et al., 2020). Apart from miRNAs, other types of RNAs in exosomes that can be used as prognostic markers, including long noncoding RNA (IncRNA) and circRNAs (Dai et al., 2020).

Regarding therapeutic strategies, exosomes have emerged as a promising vehicle for the transport and transfer of drugs, miRNAs, small interfering RNA (siRNAs), short hairpin RNAs (shRNAs), and other molecules for the treatment of malignancies or other diseases. Owing to their microscopic size, exosomes can avoid phagocytosis of mononuclear macrophages and can also penetrate the blood vessel wall and extracellular matrix. Therefore, they can act as a natural biological carrier that is stable and membrane permeable, transferring therapeutic cargos more efficiently and with fewer off-the mark effects than other bio-vehicles, such as liposomes.

Researchers reported an outstanding example of exosomes that had a cargo of siRNAs or shRNAs and use up oncogenes to suppress tumor CD47+ development (Kalluri and LeBleu, 2020). On top of that, exosomes can deliver or confer antigens derived from tumors that activate cytotoxic $T$ cells, making them an attractive prospect for anticancer vaccination. Given the ability of exosomes originated from cancer cells to cause angiogenesis, promote metastasis, and change pre-metastatic niches, removing them from the circulatory system to prevent cancer metastasis is another potential clinical application of exosomes (Zhang and Yu, 2019).

Enrichment of engineered ligand in exosomes may also be utilized to activate or inhibit different signaling pathways in recipient cells or to target specific cell types. Based on the observation that miRNA from exosomes effectively activates target mRNA and inhibits gene expression in recipient cells, the technology of exosome engineering has been developed to provide specific miRNA or siRNA payloads for CNS diseases and cancer. The involvement of exosomes in the polarization of the tumor immune microenvironment has also helped the design of therapeutic exosomes aimed at enhancing the anti-tumor immune response (Kalluri and LeBleu, 2020). In general, a wide range of therapeutic materials, including siRNAs, antagomirs, recombinant proteins, and anti-inflammatory medicines, can be encapsulated for exosome-mediated delivery using several methods (Zhang et al., 2019).

The improvement of effectiveness in cancer treatment is necessary for the successful delivery of drugs to tumor cells. To that end, examples of studies on engineered exosomes for potential therapeutic applications are presented in Table 1. Nanotechnologybased medication delivery systems are one of the most favorable clinical methods for accomplishing this purpose. Exosomes have
TABLE 1

\section{EXOSOMES ENGINEERED FOR POTENTIAL THERAPEUTIC APPLICATIONS WITH REGARDS TO TARGETING MOLECULES OR CELLS, THEIRS CONTENTS, AND DESIRABLE PURPOSES}

\begin{tabular}{|c|c|c|c|}
\hline $\begin{array}{l}\text { Targeting } \\
\text { molecule / cell }\end{array}$ & Cargo & Purpose & Reference \\
\hline Survivin & $\begin{array}{l}\text { Survivin-T34A } \\
\text { mutant }\end{array}$ & Induction of apoptosis & Aspe et al., 2014 \\
\hline iRGD & Doxorubicin & $\begin{array}{l}\text { Targeting and inhibition of tumor } \\
\text { growth }\end{array}$ & Tian et al., 2014 \\
\hline exoDOX & Doxorubicin & Inhibition of tumor growth & Hadla et al., 2016 \\
\hline IL-3 & $\begin{array}{l}\text { Imatinib and CRABL } \\
\text { siRNA }\end{array}$ & Inhibition of tumor growth & Bellavia et al., 2017 \\
\hline AS1411 aptamer & $\begin{array}{l}\text { let-7 and VEGF } \\
\text { siRNA }\end{array}$ & Targeting tumor tissues & Wang et al., 2017 \\
\hline CD47-SIRPa & SIRPA variants & Stimulate immune response & Koh et al., 2017 \\
\hline RGD & Ac4ManNAz & Angiogenesis therapy & Wang et al., 2017 \\
\hline Anti-HER2scFvs & CFSE & Targeting to cells & Longatti et al., 2018 \\
\hline AA-PEG & Paclitaxel & $\begin{array}{l}\text { Targeting cancer cells upon } \\
\text { systemic administration }\end{array}$ & Kim et al., 2018 \\
\hline miR-335 & miR-335-5p & $\begin{array}{l}\text { Targeting hepatocellular } \\
\text { carcinoma }\end{array}$ & Wang et al., 2018 \\
\hline Darpins & TPD52 siRNA & $\begin{array}{l}\text { Delivering siRNA and } \\
\text { downregulation of TPD52 }\end{array}$ & Limoni et al., 2019 \\
\hline M1-exosomes & Paclitaxel & $\begin{array}{l}\text { Antitumor activities of } \\
\text { chemotherapeutics }\end{array}$ & Wang et al., 2019 \\
\hline HT1080 & Doxorubicin & Targeting tumor tissues & Qiao et al., 2020 \\
\hline $\begin{array}{l}\text { HER } 2+\text { breast } \\
\text { cancer cells }\end{array}$ & $\begin{array}{l}\text { 5-FU and MiR-21 } \\
\text { inhibitor }\end{array}$ & $\begin{array}{l}\text { Enhancing the cytotoxicity of 5-FU } \\
\text { and reversing drug resistance }\end{array}$ & Liang et al., 2020 \\
\hline
\end{tabular}

been applied as vectors for drug and functional RNA delivery in cancer treatment because of their innate delivery capabilities. They can be taken up by cells, and stably transfer drugs in stable fashion. Paclitaxel, for instance, an antimitotic chemotherapeutic treatment, can be delivered into exosomes. Anticancer drugs and/or external non-coding RNA (ncRNA) have the ability directly to target cancer cells or cancer stem cells specific pathways after being loaded into exosomes, preventing tumor progression. Furthermore, the surfaces of exosomes can be modified by using ligands that correlate to receptors expressed on cancer cell surfaces, increasing exosome cellular absorption efficiency (Batrakova and Kim, 2015; Dai et al., 2020).

\section{Concluding Remarks}

Over the past few years, knowledge of exosomes' effects in cell-cell communication has evolved significantly. Exosomes play critical roles in both physiological and pathological processes due to their mediation of cell-cell communication, their release from a plethora of cell types, and their existence in virtually all body fluids. Exosome production and secretion appears to be influenced by the tumor microenvironment, which in turn plays a role in tumor development. It is worth noting that exosomes can regulate metastasis and ECM remodeling, as well as promote the upregulation of inflammatory molecules, induce angiogenesis and infiltration, and control immunological response.

The interaction of exosomes with ECM and TME for cancer progression turns out to be a dynamic interplay, taking place from both sides; on one hand, hypoxic conditions in TME and collagen remodeling modulate exosome formation and secretion, while their binding to receptor cells is regulated by proteins and ECM receptors. On the other hand, exosome cargo transferred to receptor cells makes exosomes important tools for metastasis. 
Thus, exosomes, rich in active components, such as heparanase, MMPs and other enzymes, miRNAs, metabolic products, and ECM components, can contribute to cancer progression by affecting key cellular functions and promoting angiogenesis and EMT.

Consequently, exosome capacity to encapsulate these components make them an up-coming diagnostic biomarker and therapeutic tool for cancer and other diseases. Exosome-based treatments include the use of naturally produced immune cell exosomes to inhibit cancer cells, suppress cancer cell-derived exosomes activities, and their use as gene or drug carriers. Further research is required however, focusing on engineering exosomes for drug delivery with features like high drug loading capacity, high specificity, non-cytotoxic effect, and low immunogenicity using in vivo models. While there are still obstacles to overcome, it is obvious that exosomes have a unique and significant function in diagnostic and therapeutic approaches.

\section{Funding}

K.K. was co-financed by Greece and the European Union (European Social Fund-ESF) through the Operational Programme "Human Resources Development, Education and Lifelong Learning", in the context of the project "Strengthening Human Resources Research Potential via Doctorate Research" (MIS-5000432), implemented by the State Scholarships Foundation (IKY).

Conflicts of interest

The authors declare no conflict of interest.

\section{References}

ASPE J. R., DIAZ OSTERMAN C. J., JUTZY J. M.S., DESHIELDS S., WHANG S., WALL N. R. (2014). Enhancement of Gemcitabine sensitivity in pancreatic adenocarcinoma by novel exosome-mediated delivery of the Survivin-T34A mutant. Journal of Extracellular Vesicles 3: 23244. https://doi.org/10.3402/jev.v3.23244

BATRAKOVA E. V., KIM M. S. (2015). Using exosomes, naturally-equipped nanocarriers, for drug delivery. Journal of Controlled Release 219: 396-405. https://doi. org/10.1016/j.jconrel.2015.07.030

BEBELMAN M. P., SMIT M. J., PEGTEL D. M., BAGLIO S. R. (2018). Biogenesis and function of extracellular vesicles in cancer. Pharmacology \& Therapeutics 188: 1-11. https://doi.org/10.1016/j.pharmthera.2018.02.013

BELLAVIA D., RAIMONDO S., CALABRESE G., FORTE S., CRISTALDI M., PATINELLA A., MEMEO L., MANNO M., RACCOSTA S., DIANA P., CIRRINCIONE G., GIAVARESI G., MONTELEONE F., FONTANA S., DE LEO G., ALESSANDRO R. (2017). Interleukin 3- receptor targeted exosomes inhibit in vitro and in vivo Chronic Myelogenous Leukemia cell growth . Theranostics 7: 1333-1345. https:// doi.org/10.7150/thno. 17092

CHERNYSHEV V. S., RACHAMADUGU R., TSENG Y. H., BELNAP D. M., JIA Y., BRANCH K. J., BUTTERFIELD A. E., PEASE L. F., BERNARD P. S., SKLIAR M. (2015). Size and shape characterization of hydrated and desiccated exosomes. Analytical and Bioanalytical Chemistry 407: 3285-3301. https://doi.org/10.1007/ s00216-015-8535-3

DAI J., SU Y., ZHONG S., CONG L., LIU B., YANG J., TAO Y., HE Z., CHEN C., JIANG Y. (2020). Exosomes: key players in cancer and potential therapeutic strategy. Signal Transduction and Targeted Therapy 5: 145. https://doi.org/10.1038/s41392020-00261-0

FRANCHI M., PIPERIGKOU Z., KARAMANOS K.A., FRANCHI L., MASOLA V. (2020). Extracellular Matrix-Mediated Breast Cancer Cells Morphological Alterations, Invasiveness, and Microvesicles/Exosomes Release. Cells 9: 2031. https://doi. org/10.3390/cells9092031

FRENCH K. C., ANTONYAK M. A., CERIONER. A. (2017). Extracellular vesicle docking at the cellular port: Extracellular vesicle binding and uptake. Seminars in Cell \& DevelopmentalBiology 67:48-55. https://doi.org/10.1016/j.semcdb.2017.01.002
GALINDO-HERNANDEZ O., SERNA-MARQUEZ N., CASTILLO-SANCHEZ R., SALAZAR E. P. (2014). Extracellular vesicles from MDA-MB-231 breast cancer cells stimulated with linoleic acid promote an EMT-like process in MCF10A cells. Prostaglandins, Leukotrienes and Essential Fatty Acids 91: 299-310. https://doi. org/10.1016/j.plefa.2014.09.002

GIORDANO C., LA CAMERA G., GELSOMINO L., BARONE I., BONOFIGLIO D., ANDÒ S., CATALANO S. (2020). The Biology of Exosomes in Breast Cancer Progression: Dissemination, Immune Evasion and Metastatic Colonization. Cancers 12: 2179. https://doi.org/10.3390/cancers12082179

GUO Y., JIX., LIU J., FAN D., ZHOU Q., CHEN C., WANG W., WANG G., WANG H., YUAN W., JI Z., SUN Z. (2019). Effects of exosomes on pre-metastatic niche formation in tumors. Molecular Cancer 18: 39. https://doi.org/10.1186/s12943-019-0995-1

HADLA M., PALAZZOLO S., CORONA G., CALIGIURI I., CANZONIERI V., TOFFOLI G. RIZZOLIO F. (2016). Exosomes increase the therapeutic index of doxorubicin in breast and ovarian cancer mouse models. Nanomedicine 11:2431-2441. https:// doi.org/10.2217/nnm-2016-0154

HARDING C., STAHL P. (1983). Transferrin recycling in reticulocytes: $\mathrm{pH}$ and iron are important determinants of ligand binding and processing. Biochemical and Biophysical Research Communications 113: 650-658. https://doi.org/10.1016/0006291X(83)91776-X

HOSHINO D., KIRKBRIDE K. C., COSTELLO K., CLARK E. S., SINHA S., GREGALARSON N., TYSKA M. J., WEAVER A. M. (2013). Exosome Secretion Is Enhanced by Invadopodia and Drives Invasive Behavior. Cell Reports 5: 1159-1168. https:// doi.org/10.1016/j.celrep.2013.10.050

JUNG W.-H., YAM N., CHEN C.-C., ELAWAD K., HU B., CHEN Y. (2020). Force-dependent extracellular matrix remodeling by early-stage cancer cells alters diffusion and induces carcinoma-associated fibroblasts. Biomaterials 234: 119756. https://doi. org/10.1016/j.biomaterials.2020.119756

KALLURI R., LEBLEU V. S. (2020). The biology, function, and biomedical applications of exosomes. Science 367:32029601. https://doi.org/10.1126/science.aau6977

KARAMANOS N. K., PIPERIGKOU Z., PASSI A., GÖTTE M., ROUSSELLE P., VLODAVSKY I. (2021). Extracellular matrix-based cancer targeting. Trends in MolecularMedicine 27:1000-1013. https://doi.org/10.1016/j.molmed.2021.07.009

KIM M. S., HANEY M. J., ZHAO Y., YUAN D., DEYGEN I., KLYACHKO N. L., KABANOV A. V., BATRAKOVA E. V. (2018). Engineering macrophage-derived exosomes for targeted paclitaxel delivery to pulmonary metastases: in vitro and in vivo evaluations. Nanomedicine: Nanotechnology, Biology and Medicine 14: 195-204. https:// doi.org/10.1016/j.nano.2017.09.011

KOH E., LEE E. J., NAM G.H., HONG Y., CHO E., YANG Y., KIM I.S. (2017). ExosomeSIRPa, a CD47 blockade increases cancer cell phagocytosis. Biomaterials 121 121-129. https://doi.org/10.1016/j.biomaterials.2017.01.004

LIANG G., ZHU Y., ALI D. J., TIAN T., XU H., SI K., SUN B., CHEN B., XIAO Z. (2020) Engineered exosomes for targeted co-delivery of miR-21 inhibitor and chemotherapeutics to reverse drug resistance in colon cancer. Journal of Nanobiotechnology 18: 10. https://doi.org/10.1186/s12951-019-0563-2

LIMONI S. K., MOGHADAM M. F., MOAZZENI S. M., GOMARI H., SALIMI F. (2019), Engineered Exosomes for Targeted Transfer of siRNA to HER2 Positive Breast Cancer Cells. Applied Biochemistry and Biotechnology 187: 352-364. https://doi. org/10.1007/s12010-018-2813-4

LIN Q., CHEN X., MENG F., OGAWA K., LI M., SONG R., ZHANG S., ZHANG Z., KONG X., XU Q., HE F., BAI X., SUN B., HUNG M.C., LIU L., WANDS J., DONG X. (2019). ASPH-notch Axis guided Exosomal delivery of Prometastatic Secretome renders breast Cancer multi-organ metastasis. Molecular Cancer 18: 156. https://doi. org/10.1186/s12943-019-1077-0

LONGATTI A., SCHINDLER C., COLLINSON A., JENKINSON L., MATTHEWS C. FITZPATRICK L., BLUNDY M., MINTER R., VAUGHAN T., SHAW M., TIGUE N. (2018). High affinity single-chain variable fragments are specific and versatile targeting motifs for extracellular vesicles. Nanoscale 10: 14230-14244. https:// doi.org/10.1039/C8NR03970D

MAAS S. L.N., BREAKEFIELD X. O., WEAVER A. M. (2017). Extracellular Vesicles: Unique Intercellular Delivery Vehicles. Trends in Cell Biology 27: 172-188. https:// doi.org/10.1016/j.tcb.2016.11.003

MASHOURI L., YOUSEFI H., AREF A. R., AHADI A. , MOLAEI F., ALAHARI S. K. (2019). Exosomes: composition, biogenesis, and mechanisms in cancer metastasis and drug resistance. Molecular Cancer 18: 75. https://doi.org/10.1186/ s12943-019-0991-5 
MATHIEU M., MARTIN-JAULAR L., LAVIEU G., THÉRY C. (2019). Specificities of secretion and uptake of exosomes and other extracellular vesicles for cell-to-cell communication. Nature Cell Biology 21: 9-17. https://doi.org/10.1038/s41556018-0250-9

MELO S. A., SUGIMOTO H., O'CONNELL J. T., KATO N., VILLANUEVA A., VIDAL A. QIU L., VITKIN E., PERELMAN L. T., MELO C. A., LUCCI A., IVAN C., CALIN G. A., KALLURI R. (2014). Cancer Exosomes Perform Cell-Independent MicroRNA Biogenesis and Promote Tumorigenesis. Cancer Cell 26: 707-721. https://doi. org/10.1016/j.ccell.2014.09.005

PAOLILLO M., SCHINELLI S. (2017). Integrins and Exosomes, a Dangerous Liaison in Cancer Progression. Cancers 9: 95. https://doi.org/10.3390/cancers9080095

PEGTEL D. MICHIEL, GOULD STEPHEN J. (2019). Exosomes. Annual Review of Biochemistry 88:487-514. https://doi.org/10.1146/annurev-biochem-013118-111902

PIPERIGKOU Z., KYRIAKOPOULOU K., KOUTSAKIS C., MASTRONIKOLIS S., KARAMANOS N. K. (2021). Key Matrix Remodeling Enzymes: Functions and Targeting in Cancer. Cancers 13: 1441. https://doi.org/10.3390/cancers13061441

QADIR F., AZIZ M. A., SARI C. P., MA H., DAI H., WANG X., RAITHATHA D., DA SILVA L. G. L., HUSSAIN M., POORKASREIY S. P., HUTCHISON I. L., WASEEM A., TEH M.T. (2018). Transcriptome reprogramming by cancer exosomes: identification of novel molecular targets in matrix and immune modulation. Molecular Cancer 17: 97. https://doi.org/10.1186/s12943-018-0846-5

QIAO L., HUS., HUANG K., SU T., LI Z., VANDERGRIFF A., CORES J., DINH P.U., ALLEN T., SHEN D., LIANG H., LI Y., CHENG K. (2020). Tumor cell-derived exosomes home to their cells of origin and can be used as Trojan horses to deliver cancer drugs. Theranostics 10: 3474-3487. https://doi.org/10.7150/thno.39434

RILLAK., MUSTONENA.-M., ARASUU. T., HÄRKÖNEN K., MATILAINEN J., NIEMINEN P. (2019). Extracellular vesicles are integral and functional components of the extracellular matrix. Matrix Biology 75-76: 201-219. https://doi.org/10.1016/j. matbio.2017.10.003

SZVICSEK Z., OSZVALD Á., SZABÓ L., SÁNDOR G. O., KELEMEN A., SOÓS A. Á., PÁLÓCZI K., HARSÁNYI L., TÖLGYES T., DEDE K., BURSICS A., BUZÁS E. I., ZEÖLD A., WIENERZ. (2019). Extracellular vesicle release from intestinal organoids is modulated by Apc mutation and other colorectal cancer progression factors. Cellular and Molecular Life Sciences 76: 2463-2476. https://doi.org/10.1007/ s00018-019-03052-1

TAI Y.L., CHEN K.C., HSIEH J.T., SHEN T.L. (2018). Exosomes in cancer development and clinical applications. Cancer Science 109:2364-2374. https://doi.org/10.1111/ cas. 13697

TAN Y., LUO X., LV W., HU W., ZHAO C., XIONG M., YIY., WANG D., WANG Y., WANG H., WUY., ZHANG Q. (2021). Tumor-derived exosomal components: the multifaceted roles and mechanisms in breast cancer metastasis. Cell Death \& Disease 12: 547. https://doi.org/10.1038/s41419-021-03825-2
TIAN Y., LI S., SONG J., JI T., ZHU M., ANDERSON G. J., WEI J., NIE G. (2014) A doxorubicin delivery platform using engineered natural membrane vesicle exosomes for targeted tumor therapy. Biomaterials 35: 2383-2390. https://doi. org/10.1016/j.biomaterials.2013.11.083

TRAJKOVIC K., HSU C., CHIANTIA S., RAJENDRAN L., WENZEL D., WIELAND F. SCHWILLE P., BRÜGGER B., SIMONS M. (2008). Ceramide Triggers Budding of Exosome Vesicles into Multivesicular Endosomes. Science 319: 1244-1247. https://doi.org/10.1126/science. 1153124

VAN NIEL G., CHARRIN S., SIMOES S., ROMAO M., ROCHIN L., SAFTIG P., MARKS M. S., RUBINSTEIN E., RAPOSO G. (2011). The Tetraspanin CD63 Regulates ESCRT-Independent and -Dependent Endosomal Sorting during Melanogenesis. Developmental Cell 21: 708-721. https://doi.org/10.1016/j.devcel.2011.08.019

VAN NIEL G., PORTO-CARREIRO I., SIMOES S., RAPOSO G. (2006). Exosomes: A Common Pathway for a Specialized Function. The Journal of Biochemistry 140 13-21. https://doi.org/10.1093/jb/mvj128

WANG F., LI L., PIONTEK K., SAKAGUCHI M., SELARU F. M. (2018). Exosome miR335 as a novel therapeutic strategy in hepatocellular carcinoma. Hepatology 67: 940-954. https://doi.org/10.1002/hep.29586

WANG J., LI W., LU Z., ZHANG L., HU Y., LI Q., DU W., FENG X., JIA H., LIU B.F. (2017). The use of RGD-engineered exosomes for enhanced targeting ability and synergistic therapy toward angiogenesis. Nanoscale 9: 15598-15605. https://doi. org/10.1039/C7NR04425A

WANG S., QIU Y., BAI B. (2019). The Expression, Regulation, and Biomarker Potential of Glypican-1 in Cancer. Frontiers in Oncology 9: 614. https://doi.org/10.3389/ fonc. 2019.00614

WINKLER J., ABISOYE-OGUNNIYAN A., METCALF K. J., WERB Z. (2020). Concepts of extracellular matrix remodelling in tumour progression and metastasis. Nature Communications 11: 5120. https://doi.org/10.1038/s41467-020-18794-X

YANG J., BAHCECIOGLU G., ZORLUTUNA P. (2020). The Extracellular Matrix and Vesicles Modulate the Breast Tumor Microenvironment. Bioengineering 7: 124. https://doi.org/10.3390/bioengineering7040124

ZHANG L., YU D. (2019). Exosomes in cancer development, metastasis, and immunity Biochimica et Biophysica Acta (BBA) - Reviews on Cancer 1871: 455-468. https:// doi.org/10.1016/j.bbcan.2019.04.004

ZHANG Y., BI J., HUANG J., TANG Y., DU S., LI P. (2020). Exosome: A Review of Its Classification, Isolation Techniques, Storage, Diagnostic and Targeted Therapy Applications. International Journal of Nanomedicine Volume 15: 6917-6934. https://doi.org/10.2147/IJN.S264498

ZHANG Y., LIU Y., LIU H., TANG W. H. (2019). Exosomes: biogenesis, biologic function and clinical potential. Cell \& Bioscience 9: 19. https://doi.org/10.1186/ s13578-019-0282-2 